\title{
Vitryssland eller Belarus?: Namnskick, långdistansnationalism och identitetspolitik
}

\author{
Per Anders Rudling* \\ Wallenberg Academy Fellow, Historiska institutionen, Lunds universitet, Sverige
}

\begin{abstract}
In 2019, the Swedish government officially switched terminology from using the traditional endogenous term Vitryssland to the exogenous Belarus. Vitryssland (lit: White Russia) had been in use in the Swedish language since the $17^{\text {th }}$ century, and the decision was neither easy nor swift. There was no consensus about the utility of the change, and significant opposition from linguists and editors against abandoning a term which had emerged and become established over centuries of contact. The debate preceding the switch was often shrill, led by activists and steeped in identity politics. In fact, controversies regarding what to call the country were nothing new, highlighting diverging visions of its geopolitical and cultural position between East and West. Discussions mirrored the far more emotional and polarized discussions among Belarusian nationalists in the $20^{\text {th }}$ century, which at times became violent. Kryvia, Byelorussia, Greatlitva were but some of contenders. This article is an attempt to place discussions about the Swedish terminology in the larger context of history, memory, geopolitics and identity politics.
\end{abstract}

Keywords: Belarus, long distance nationalism, endonyms, Rus', Belarusian-Swedish relations

\section{Introduktion}

År 2020 fick vi i svenska språket ett nytt ord: Belarus, med avledningarna belarusier, belarusiska, belarusiskt. Denna neologism har inte varit okontroversiell utan föregåtts av en stundom ganska hätsk debatt, där aktivister och intressegrupper sökt påverka tidningsredaktioner, myndigheter och språkgranskare att överge en mycket gammal - och väletablerad exonym. Till skillnad från tidigare liknande kampanjer var denna framgångsrik. År 2020 bytte en stor del av det officiella Sverige exonymen Vitryssland mot endonymen Belarus. Varför har frågan om hur detta land och folk ska kallas varit så polariserande, och varför övergav det officiella Sverige den endogena termen Vitryssland för en främmande, och för det stora flertalet okänd och

\footnotetext{
^Kontaktinformasjon: Per Anders Rudling, e-post: Per_Anders.Rudling@hist.lu.se 
svåruttalad endonym? Denna artikel ämnar ge bakgrund och historisk kontext till frågan hur vi på svenska benämner vårt kanske mest obekanta grannland.

\section{Varför «Vitryssland»?}

Namnets ursprung är omtvistat, och något definitivt svar lär vi aldrig få. Enligt en teori skulle termen beteckna avsaknaden av en tributär relation till mongolerna efter invasionen på 1240-talet. Andra teorier söker förklara detta med referenser till vitryssarnas pigmentering eller färgen på lokala folkdräkter. Ytterligare en möjlig förklaring som givits är att förleden belyj/belaja, likt ordet balt, skulle kunna härledas etymologiskt "tillbaka på det östslaviska ordet för kärr eller sumpmark, baloto» (Karlsson, 1996, s. 4).

Det historiska Vitryssland utgörs framför allt av områden som idag utgör Mahileu och Vitsebsk län. Att härleda betydelse och ursprung för mycket gamla ortsoch landsnamn är ofta svårt. Förvirringen blir inte mindre av att dessa territorier historiskt haft ganska flytande gränser, och att betydelserna varierat över århundradena. Kartor från 1600-talet använder namnet Rus' Belaia för den östliga delen av nuvarande Republiken Belarus'.

Det historiska namnet för området runt Navahrudak, Hrodna, Slonim och längs Memelflodens övre flöden benämns Svartryssland, Rus'Tjernaja, Russia eller Ruthenia Nigra. ${ }^{1}$ Senare kartor använde samma namn för de östliga och centrala delarna av nuvarande Belarus, det som idag är den sydvästra delen av republiken Belarus, området runt Slonim, Navahrudak och Slutsk. Även här finns olika teorier till namnets ursprung. En tolkning är att Svartryssland skulle ha kristnats senare, en annan att Svartryssland lytt under tatarerna, till skillnad från Vitryssland (Sjirjajev, 1991, s. 9-10).

En ytterligare komplicerande faktor är att det område som idag utgör de centrala och västliga delarna av Republiken Belarus' tillhörde det historiska Litauen och att flera av dess ortnamn härleds därifrån. Historiestudenter är bekanta med freden i Brest-Litowsk. Fram till nyligen kallades den stad som numera är huvudstad i Republiken Belarus' Minsk-Litovskij. På samma sätt har vi också ett KamenetsLitovskij. Dubbelnamn och bindestreck markerar alltså vilket Brest, Minsk och Kamenets vi har att göra med, så att vi ska kunna särskilja det litauiska Minsk, Brest eller Kamenets från Minsk-Mazowecki, Kamenets-Podilskij, alltså Minsk i Masovien, Kaments i Podolien och Brest i Bretagne, inte olikt hur vi i svenskan använder Munka-Ljungby eller Dals Rostock för att undvika förväxling med andra orter med samma namn. Historiskt sett är huvuddelen av det område som idag utgör den självständiga republiken Belarus' det som var den litauiska delen av Rzeczpospolita Obojga Narodów, det polsk-litauiska samväldet. Söder om Vitryssland finner

\footnotetext{
${ }^{1}$ Tyskan har, vid sidan av Schwartzrußland och Schwartzruthenien även uttrycket Schartzreußen, som idag används i akademiska arbeten (Niendorf, 2006, s. 24, 30).
} 
vi ett område som på svenska kallades Rödryssland, Tjervona Rus' på ukrainska, Ruś Czerwona på polska, Russia eller Ruthenia Rubra på latin. Dessa är huvudsakligen ortodoxa östslaviska områden som på 1300-talet kom att integreras i Rzeczpospolita (Łatyszonek, 2006; Magocsi, 1983, 65-67). Efter den första delningen av Polen 1772 tillägnade sig habsburgarna detta territorium under namnet Galizien och Lodomerien (Vushko, 2015, s. 5; Wolff, 2010, s. 1-6).

Vad som varit kontroversiellt i den svenska kontexten är det andra ledet i ordet Vitryssland, och det är till stor del beroende på att svenskan inte har ett eget ord för Rus', en etnisk gemenskap av östslaviska folk baserad på en gemensam religiös tradition - ortodox kristendom - samt ett östslaviskt språkkontinuum (Bodin, 2006, s. 58-60). Russkij, avlett av Rus, betecknar någon som tillhör denna gemenskap. Ryssland (Rossija) syftar däremot på den ryska staten och ordet rossiijanin ("ryssländare») avlett av Ryssland (Rossija) betecknar någon som är medborgare i Ryska federationen oavsett etnicitet. Benämningen Vitryssland skulle därför kunna tolkas som att den knyter denna nu självständiga stat till Ryssland. Avledningen "-rus'» $\mathrm{i}$ Belarus' signalerar en etnisk gemenskap med Rus' snarare än en politisk gemenskap med Rossija. Man kan på ryska vara russkij utan att vara rossijanin och vice versa. Då svenskan saknar dessa distinktioner mellan rus' (någon som identifierar sig med östslavisk östkristen tradition), russkii (etnisk ryss) och rossijanin (»ryssländare», medborgare i Ryska federationen), leder detta lätt till missförstånd. Endonymen Belarus skulle på så sätt kunna nyansera svenskarnas bild av de östslaviska folken genom att synliggöra de östslaver som inte önskar vara del av staten Ryssland, och därmed uppfattas stödja deras politiska emancipation från den ryska staten. ${ }^{2}$

\section{Endonymer och exonymer}

Endonymer eller exonymer finns i alla språk och deras existens är i sig varken något dramatiskt eller konstigt. Endonym är det begrepp som används för ortnamn som talas lokalt på den ort som beskrivs med ortnamnet, medan exonym är namn utomstående kallar orten eller landet (Kronsteiner, 1974). Endonymer är inte sällan färgstarka och vittnar om månghundraåriga kontakter - de är sällan "korrekta» utan reflekterar i varierande utsträckning såväl okunskap som fördomar. Vissa är förknippade med kontroverser, såsom ordet $\dot{z} y d$ för jude, som i polskan är den etablerade och allmänt använda termen, samtidigt som ordet zhid på ryska har en starkt nedsättande och pejorativ innebörd. I ukrainskan och vitryskan, där man finner såväl det från polskan inlånade zhyd som ryskans evrej, jevrej (ukrainska), habrei och jaurei (belarusiska/vitryska) - alltså svenskans motsvarighet till hebré - har ordvalet utlöst polariserande diskussioner. Inte alls lika kontroversiella är forntyskans Walh, senare Walch och Welsche som användes först för kelter och sedan romare, för att

${ }^{2}$ Om liknande diskussioner i den engelska terminologin, se Astapova, 2018; Zaprudnik, 1974, 1975a, $1975 b$. 
sedan komma att användas som endonym för talare av romanska språk. Samma rot - välskan - ligger till grund för Wales och walesiska i flera germanska språk. I svenskan refererades det som idag är Italien som Välskaland, en referens till det vulgärlatin, eller rotvälska, som ansågs tala på halvön. På polska kallas Italien fortfarande Wtochy. De nordliga landskapen i Sverige och Finland kallas båda Lappland, samtidigt som ordet lapp och lappska idag kan uppfattas som pejorativa. Listan på etablerade termer som vuxit fram organiskt över århundradena kan naturligtvis göras mycket längre. De belarusiska/vitryska endonymerna för tyskar och Tyskland är nemtsy eller Njametjtjyna, alltså bokstavligen "stumma» och "Stummaland». Namnfrågan har oundvikligen en politisk aspekt. Tolkningen att dylika endogena termer utgör historiska uttryck för respektlöshet och missaktning är naturligtvis möjlig. En annan och enligt författaren mer rimlig tolkning är emellertid att söka placera dem i sin historiska kontext som en avspegling av interkulturella kontakter och en gemensam historia.

Likt den lokale, nordiskättade polatskfursten Ragnvald blev Rogvolod och hans dotter Ragnhild blev Rogvalda i de lokala slaviska munarterna på 1000-talet har även nordbor utvecklat namnformer som låg "rätt i mun", gick att uttala och kunde inordnas i ett lokalt namnskick. Att Belarus' för den genomsnittlige svensken känns obekvämt, artificiellt och klumpigt är uppenbart för svensktalande med kunskaper i östslaviska språk. Under de månader som gått sedan media bytte från Vitryssland till Belarus har svenska radiolyssnare hört journalister och reportrar kämpa med uttalet av den för dem uppenbarligen främmande endonymen Belarus; vi har hört "Bjelaruus", "Belaryss", "Bellaruss", "Bellarus» med långa och korta såväl "e» som "ü", "y» och "O». Det tonlösa alveolopalatala frikativa "s'» i vitryskan/belarusiskans lacinka "ś» försöker få sig på. Det blir alltså en "försvenskning» eller "exogenisering» av endonymen Belarus'. Svårtuttalade och ovana ord finner med tiden ofta en väg in i språket, även om uttalet modifieras efter den lokala munarten. Sådana förändringar ska inte främst ses som uttryck för politisk okänslighet eller arrogans, utan förstås kanske bättre i ljuset av språk- och uttalsregler, där främmande och svåruttalade konsonanter försvinner. Resultatet hade med all sannolikhet varit mycket snarlikt om situationen varit den omvända - och modersmålstalare av vitryska anmodats ersätta deras exonyma Sjvetsyja med det endonyma "Sverige».

Försöken att tillägna sig den nypåbjudna och något svårbemästrade endonymen Belarus ska kanske även ses mot en tvetydig trend att "internationalisera» svenska namn, vilket $i$ en del fall gjort deras historiska och geografiska anknytning otydlig eller rentav obegriplig. På 1980-talet fick Skånska Cementgjuteriet bli Skanska, Götabanken Gotabanken. Det för icke-skandinaver svåruttalade Växjö universitet fick år 2010 ett namn som anpassats till en internationell (läs: engelskspråkig) miljö: Linneaus University. Vi ser alltså två något motsägelsefulla processer som löper parallellt här; svenska namn anglifieras under pretext av »internationalisering» för att underlätta uttal och därmed kommunikation, samtidigt som främmande, obekanta och manifest svåruttalade endonymer introduceras i språket. Det 
nya namnskicket kan paradoxalt nog ses som en "internationalisering» - där vi med Belarus (the Republic of Belarus) tar över ett namnskick från det enda utländska språk snittsvensken behärskar: engelskan.

NamnetVitrysslands seglivade livskraftighet bör ses mot bakgrunden av århundraden av gemensam historia. Det officiella Sverige förefaller ha haft lättare att byta namn på mer avlägsna länder till vilka våra kulturella och historiska band är svaga. Historikern Dick Harrison noterar:

Historiskt sett har vi aldrig varit konsekventa när det kommer till att ändra namn på andra stater. Under röda khmerernas tid ville makthavarna i Phnom Penh driva igenom att alla skulle skriva Kampuchea istället för Kambodja, trots att man själv fortsatte att använda gamla franska termer på omvärldsnationerna. Vi lydde, men bytte igen när regimen fallit. I Elfenbenskusten (som till skillnad från andra afrikanska länder dessutom valt att behålla sitt kolonialt klingande namn även efter självständigheten 1960) har politikerna sedan 1985 krävt att vi skall stava nationsnamnet Côte d'Ivorie, vilket betyder samma sak men på franska. I Sverige har vi bara hörsammat detta till hälften: vi kallar folket ivorianer, men fortsätter att kalla landet Elfenbenskusten. (Harrison, 2020)

Det finns fler exempel. Kongo blev på anmodan snabbt Zaïre (för att sedan återigen bli till Kongo) och Övre Volta blev relativt friktionsfritt till Burkina Faso. Ett rimligt antagande är att kung Mswati III:s dekret av den 19 april 2018 att hans rike med omedelbar verkan ska kallas Konungariket eSwatini kommer att omges av mindre känslor och debatt än den mer decennielånga namnstriden om Belarus/Vitryssland.

\section{"Vitryssland» - en gammal form i germanska, baltiska och östersjöfinska språk}

Senast på 1300-talet började folk i omvärlden bruka den latinska formen Alba Russia, som under 1600-talet kom att översättas till de olika folkspråken. I svenskan har landet refererats till som Vitryssland sedan 1600-talet. På Olaus Magnus Carta Marina från 1539 är området till öster om Peipussjön markerat som "RVSSIA ALBA», medan området runt Pskov - som vid den här tidpunkten ännu inte lydde under Moskvafurstendömet - benämns "RVSSIA Regalis nigra» (Daukšytė, 2010, s. 24-25). I sin Historia om de nordiska folken, publicerad i Rom 1555, nämner Olaus Magnus "den fruktansvärda slughet och förfarenhet, som ruthenerna eller moskoviterna lägga $i$ dagen, när det gäller röfveri till lands och vatten». De tryckta nyckelorden i marginalen av boken nämner "Moskoviters och rutherners grymhet», ${ }^{3}$ en spegling av hur de östkristna slaverna i det historiska Litauen och Moskovien betraktades som skilda grupper (Magnus, 2001 [1555], s. 495, 496). Något senare dyker namnet upp i ett sammanhang som påminner om en självidentifikation. När den kalvinistiske skriftställaren Salamon Rysinski från Vitsebsk-området (ca 1569-1626) skrev in sig vid

\footnotetext{
${ }^{3}$ Kursivering tillagd.
} 
universitetet i Leipzig vid Altdorf år 1586 under namnet Solomo Pantherus Leucorussus använde han termen leucorussus, alltså "vitryss" på grekiska (Bely, 2000, s. 153; Kotljarchuk, 2007, s. 50). Han har ibland anförts som den förste självidentifierade vitryssen - även om nationalitet och identitet naturligtvis hade en annan betydelse under tidigmodern tid än vad vi idag läser in i begreppen.

Kort därefter dök termen upp i det svenska språket. "Vissa menar», noterar språkvetaren Ola Karlsson,

att Vitryssland snarare är en sentida översättning från ryskans namn Belorussia, i betydelsen 'det vita Ryssland', och att det är en avspegling av rysk imperialism gentemot Vitryssland. Men namnet Vitryssland har lång hävd i svenskan; Svenska Akademiens ordbok har belägg på det och på orden vitryss och vitrysk sedan 1600-talet, alltså långt före den ryska imperialism som rådde under framför allt 1800-talet. (Karlsson, 2020)

"Vitryssland» i dess olika former är sålunda en namntradition som är mycket gammal och väletablerad i de germanska, baltiska och östersjöfinska språken. Termen reflekterar grannländernas månghundraåriga kulturella, historiska, och merkantila kontakter; vi finner detta inte blott i norskans Hviterussland/Kviterussland, tyskans Weißrussland ${ }^{4}$ och nederländskans Wit-Rusland, utan även i de baltiska språken: Baltkrievija på lettiska (»Krievija» är paradoxalt nog »Ryssland» på lettiska), Baltarusija på litauiska. Därtill i de östersjöfinska språken: Valko-Venäjä på finska och Valgevene på estniska. ${ }^{5}$

Det tyska språket, som med en lång tradition av att använts som förvaltningsspråk i habsburgska Galizien, av tyskbaltiska adelsmän i Baltikum såväl som av ockupationsmakterna under nittonhundratalets världskrig, har fler nyanser än de skandinaviska och finska språken och gör en finare distinktion mellan Weißrussland och Weißruthenien. ${ }^{6}$ Ordet Ruthenien/Rutenien och ruthener/rutener förekommer likväl i svenska diplomatrapporter från 1920-talet, som en synonym till lillryssar. Kunskapen om befolkningsgrupperna i Galizien, Volhynien och Västvitryssland är begränsad, och där råder en betydande begreppsförvirring. ${ }^{7}$

\footnotetext{
${ }^{4}$ Tyskan har två uttryck. Den historiska termen för den östslaviska befolkningen i det historiska Litauen var Weißruthenien, som på 1800-talet, efter Polens uppdelning, alltmer kom att ersättas av Weißrussland. Historikern Diana Siebert menar att Weißruthenien egentligen är den mest adekvata beteckningen för området, då det ger den distinktion från det ryska, samtidigt som det p.g.a. dess användning av naziregimen gör det belastat och därför olämpligt (Siebert, 1998, s. 24).

${ }^{5}$ Finskan och estniskan anpassar uttalet av utländska namn av fonetiska skäl: »Tukholma» istället för Stockholm. Namn som börjar på B är för talare av dessa språk svårare att uttala och palataliseras. Berlin uttalas snarare som »Perlin", och skulle de exonyma namnen på de östersjöfinska språken överges till förmån för endonymen Belarus, skulle uttalet bli ungefär "Pella-roos».

${ }^{6}$ De nazityska ockupationsmyndigheterna använde officiellt Weißruthenien, även om användningen av Weißrussland kom att öka 1944-1945 (Ranitsa, 1942, 1943, 1945).

${ }^{7}$ Däremot finns i rapporterna ingen motsvarighet till tyskans Weißruthenen. Befolkningen benämns konsekvent vitryssar (Sehn, 1994, s. 141-155). Sveriges envoyé Per Anckarsvärd rapporterade från Warszawa till UD i Stockholm om »Ruthenien eller Lill-Ryssland, som för övrigt alldeles oegentligt blivit kallat Ukraina» (Rudling, 2011a, s. 32-33).
} 


\title{
Det sovjetiska "Bjeloryssland»
}

Uppkomsten av en separat vitrysk identitet är i mångt och mycket ett resultat av den geopolitiska maktkampen mellan tyskar, polacker, litauer och sovjeter under första världskriget och dess följdkonflikter. Den säsongsstat, Belaruskaja narodnaja respublika (BNR) som utropades i mars 1918, benämndes på svenska självfallet vid sitt sedan länge etablerade namn (Michaluk, 2010). Hufvudstadsbladet rapporterade i januari 1920 att

\begin{abstract}
Ehuru hela Vit-Ryssland är ockuperat av polska trupper och underlyder den polska regeringen, har Finland erkänt Vit-Ryssland som en självständig stat och tillåter dess representant att utöva konsularverksamhet här i staden. Då Vit-Ryssland icke blivit erkänt av någon annan makt, ha de av den vitryska konsuln i Helsingfors utfärdade passen blott ett kuriositetsvärde. (Tiander, 1920)
\end{abstract}

Öster om den polsk-sovjetiska fronten argumenterade Stalin och Lenin för existensen av en distinkt, vitrysk nation. 1 januari 1919 upprättades den Vitryska socialistiska sovjetrepubliken (vitryska SSR) i syftet att "rota» och konsolidera bolsjevikernas kontroll genom skapandet av en nationellt medveten kader av vitryska nationalkommunister i enlighet med Stalins formel »nationell till formen, proletär till innehållet» (Stalin, 1954, s. 138). Vitryska SSR var i mycket hög grad ett resultat av den sovjetiska nationalitetspolitiken (Marková, 2016). Stalintidens terror hade paradoxala konsekvenser för republiken; blomman av den vitryskspråkiga eliten föll offer för terrorn. Samtidigt innebar 1930- och 1940-talens mycket omfattande politiska våld att den etniskt vitryska befolkningsgruppens dominans stärktes. En mycket stor del av republikens betydande judiska befolkning mördades i Förintelsen, medan mycket av den polska minoriteten, redan decimerad under Stalinterrorn, tvångsförflyttades efter kriget till folkrepubliken Polen. I deras ställe strömmade vitryssar från landsbygden in till städerna, där de kom att inordnas i en alltmer ryskspråkig miljö (Ackermann, 2010, s. 328-329; Bohn, 2008, s. 54-65). Näst Armeniska SSR kom Vitryska SSR att bli Sovjetunionens etniskt mest homogena republik.

Fram till 1938 var Vitryska SSR officiellt fyrspråkigt.Vitryska, ryska, jiddisch och polska var alla formellt likaberättigade nationalspråk (Bemporad, 2013; Sloin, 2017; Yocum, 2003). Där fanns alltså fyra, juridiskt jämställda namnformer: Belaruskaja Savetskaja Satsyjalistytjnaja Respublika, Belorusskaja Sovetskaja Sotsijalistitjeskaja Respublika, Di veysrusishe sotsialistishe sovetn-republik, Biatoruska Socjalistyczna Republika Radziecka. Formellt använde sovjetregimen sålunda en adjektiviserad form av såväl det vitryska Belarus', det ryska Belorussija, det polska Biatoruś som jiddischens Veysrusland. Efter det att jiddisch och polska förlorade sin status som officiella språk 1938 kallades republiken Belarussija och Belarus' på de två kvarvarande officiella språken. På samma sätt använde de andra unionsrepublikernas språk exonymer för att benämna republiken, till exempel Baltarusijos TSR och Baltakrivijas PSR, i de litauiska och lettiska grannrepublikerna.

Samtidigt som de använde de etablerade endogena namnen för republiken i de andra republikspråken, introducerade sovjetmyndigheterna neologismer för 
republiken på främmande språk. I svenskspråkiga sovjetiska publikationer användes termen Beloryssland och belorysk, ibland med ett translittererat jekanje. Den svenska översättningen av Stalins verksamhetsberättelse på Sovjetunionens kommunistiska partis (SUKP) sjuttonde kongress år 1934 refererar sålunda till "Bjeloryssland ${ }^{8}$ medan Georgij Malenkov i den officiösa svenska översättningen av verksamhetsberättelse från SUKP:s nittonde kongress 1952 konstaterade att "Beloryssland har samlat hela det beloryska folket inom en enhetlig familj» (Malenkov, 1974 [1953], s. 93). På ett liknande sätt användes i DDR termen Belorußland (Seeger et al., 1955).

Att, som ibland gjorts i de svenska diskussionerna, knyta det endogena svenska namnet "Vitryssland» till sovjetisk tradition och namnskick är sålunda felaktigt. Inte bara är det svenska namnet betydligt äldre än Sovjetunionen; det är äldre än det ryska imperiet.

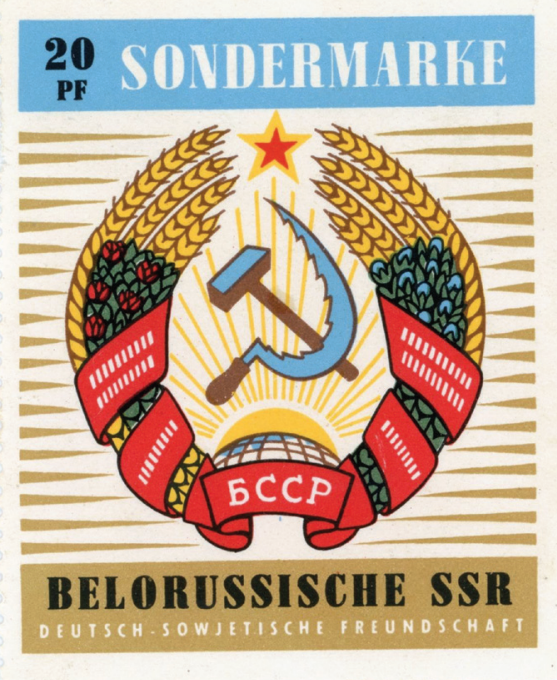

Figur 1. Specialfrimärke utgivet i DDR för femtioårsjubileet av oktoberrevolutionen. "Belorussische SSR: Deutschsowjetische Freundschaft» 1967. Museum Berlin-Karlhorst. https://berlin.museumdigital.de/singleimage.php?imagenr $=84517$

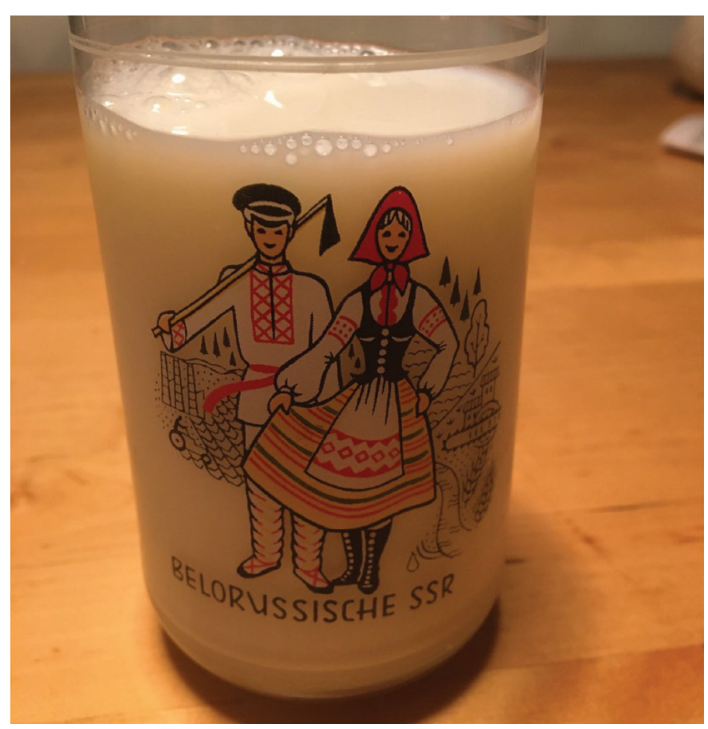

Figur 2. "Belorussiche SSR» dricksglas, DDR, circa 1970. Foto Per Anders Rudling.

\section{Nationalistisk mytologi och namnfrågan som politiskt sprängstoff}

För nationalister är det viktigt att ha en lång historia. Ju äldre nationens historia, desto högre - med nationalismens logik - är dess legitimitet. Geografen E. E.

\footnotetext{
${ }^{8}$ Den svenska översättningen utgavs 1952 (Stalin, 1952, s. 684).
} 
Sjirjajevs Vita Rus', Svarta Rus'i kartor som utgavs 1991, då landet stod på tröskeln till självständigheten, har ett primordialistiskt anslag: "Befolkningen i den vitryska delen av Litauen refererade till sig själv oftast som litviner (ibland krivitjer), men talade vitryska och betraktade sig som slaver, krivitjer» (Sjirjajev, 1991, s. 11).

Den vitryske historikern Anatol' Taras (2016) menar att för att vitryssarna ska uppleva att de har en fast identitet måste de ges en lång historia att känna sig delaktiga i. Då en självständig stat saknats före 1991 har en lösning varit att skriva storfurstendömet Litauens historia som det medeltida Belarus' historia, även om historieböckerna som regel undviker att framställa storfurstendömet Litauen som en vitrysk nationalstat (Brandt Larsen, 2017, s. 112). Taras anspråk på förhistorien baseras på etnicitet; från antiken till medeltiden bodde baltisktalande stammar "på Belarus'» territorium, därefter slavisktalande stammar: "Vi har bott på vår mark i minst 3500 år» (Taras, 2016, s. 18).

I den självständiga republiken Belarus' första konstitution får detta uttryck i dess första passus att »Vi Folket i Republiken Belarus’... Erkänner oss själva som en fullvärdig medlem av det internationella samfundet ... stödda på den månghundraåriga utvecklandet av belarusisk statlighet» (Kotljarchuk, 2004, s. 45). ${ }^{9}$ De primordiala anspråken är lika starkt betonade i den alternativa, eller oppositionella historieskrivningen. Uladzimir Arlau och Henadz' Sahanovitj gav 2002 ut en bok med titeln Tio sekler av vitrysk historia (862-1918), där storhertigdömets historia ses som en vitrysk förhistoria till den vitryska folkrepublik (Belaruskaja Narodnaja Respublika, BNR) som utropades i mars 1918. Arlau skriver att "I historiens gryning bosatte sig slaver till sydöst om Östersjön, där olika baltiska stammar bodde; en konfederation av stammar, krivitjer, grundade år 862 en proto-belarusisk stat med huvudstad i Polatsk». Därefter följer kapitel med namn som "Det förhistoriska Belarus», "De äldsta belarusiska furstendömena», "Litauiska Storfurstendömet», "Belarus i Rzeczpospolita» samt Belarus' i det ryska imperiet»(Gerner, 2021, s. 18-19; Ioffe, 2008, s. 66-67).

Barbara Törnquist-Plewa ser försöken av nationellt sinnade vitryska historiker att ge vitryssarna monopol på storfurstendömet Litauens statstradition

som ett desperat sökande efter de protonationella rötter som saknas i vitryssarnas historiska tradition. Det är ett sätt att genom en omtolkning av historien skaffa sig en egen och enbart egen statstradition. Denna omtolkning görs genom att man tillämpar dagens nationella kriterier på de medeltida förhållandena. Det är ett anakronistiskt förfaringssätt som ger anledning att ifrågasätta [dessas] trovärdighet som historiker. (Törnquist-Plewa, 1997, s. 24)

Vitryssland? Beloryssland? Bjeloryssland? Belarus'? Krivitjien? Storlitauen? Namnfrågan har under ett århundrade varit politiskt sprängstoff för vitryska nationalister, i synnerhet dem som sökte maximera det avståndet till moskoviterna

\footnotetext{
${ }^{9}$ Kotljarchuks emfas.
} 
eller "storryssarna». Diskussionerna bland de vitryska nationalisterna under nittonhundratalets första hälft speglade liknande diskussioner om ras, blod och arv inom andra europeiska nationella rörelser. En skola menade att vitryssarna var det rasmässigt "renaste» slaviska folket, relativt fritt från mongoliska, tatariska och finsk-ugriska genetiska influenser (Rudling, 2015, s. 118). En annan insisterade tvärtom på att vitryssarna överhuvudtaget inte var slaver utan ett fjärde baltiskt folk, baserat på ett baltiskt eller möjligen balto-slaviskt "substratum». Definitionerna var och är ofta luddiga och skiftar mellan rasliga, genetiska och lingvistiska markörer.

Prästen, aktivisten och akademikern Uladislau Ryzy-Ryski (1925-1978) publicerade 1960 en karta med titeln "Byelorussian tribes in the 10th Century", där han med stor precision placerade åtta "Vitryska stammar» inom Vitrysslands "etnografiska gränser» på 900-talet (Ryzy-Ryski, 1960, s. 1). Den kanske viktigaste av dessa proto-vitryska stammar skulle, enligt denna nationalistiska skola, vara just krivitjerna. En liknande tankefigur inleder Ivan Kasiaks (1909-1989) arbete om Vitrysslands historia från 1989, som presenterar det vitryska etnoset som en sammansmältning av krivitjer och fyra andra folk som han kunde namnge med stor precision (Kasiak, 1989, s. 7). ${ }^{10}$ Med stöd av den tyske 1800-talsantropologen Theodor Poesche (1825-1897) hävdade Kasiak att det "vitryska folkets rasliga ursprung» sammanföll med "den ariska rasens urhem» ${ }^{11}$ (Kasiak, 1989, s. 4).

Den sovjetiska rasbiologins nestor Viktor V. Bunak (1891-1979) argumenterade 1932 att "Krivitjerna utmärktes av deras höga växt, långskallighet (dolikocefali), smala ansikten, markerade krökta näsor och välmarkerade hakor - typiska för valdai-typen och mer allmänt för den nordiska rastypen». Bunak drog slutsatsen att krivitjerna delade ett gemensamt långskalligt dolikocefalt ursprung med allemanderna, som representanter för den nordiska folkstypen, samt med den sublaponida folkstypen (Veksler, Rabinovitj \& Sjeljapina, 1973; Aleksejeva, 1973, s. 4). Den sovjetiska rasantropologiska traditionen (ry: rasovedenie) med dess teoribyggnad runt etnogenesis, genofond, och substrat har behållit en betydande popularitet i den post-sovjetiska världen (Ackermann, 2010, s. 27, n.120). ${ }^{12}$ Den officiella historiografin i Republiken Belarus' nämner särskilt tre forntida östslaviska stammar - krivitjer, dregovitjer och radimetjer som skulle ha trängt in på det territorium som idag utgör landets territorium mellan 600- och 800-talen, och som då skulle varit befolkat av baltiska stammar som jatvinger och litauer; ett

\footnotetext{
${ }^{10}$ Kasiak var under andra världskriget aktiv i det pro-tyska Vitryska Centralrådet (Belaruskaja Tsentral'naja Rada), och kom i emigrationen att befinna sig i opposition mot Abramtjyks BNR.

${ }^{11}$ Theodor Poesche framförde sitt idag mycket daterade och antikverade argument i Die Arier: Ein Beitrag zur historischen Anthropologie (Poesche, 1878).

${ }^{12}$ För liknande estoeriska diskurser i skärningspunkten mellan språk, etnicitet och rasmysik i den litauiska litteraturen se Rudling, 2017, s. 97-100.
} 
"balto-slaviskt substrat» ur vilket ett vitryskt etnos uppstått (Kotljarchuk, 2004, 48-49). Antropologen Aljaksej Mikulitj (1934-2021) menade att ursprungsbefolknngen i området längs floden Dvinas delar gemensamma krivitjiska genetiska rötter och att "antropo-genetiska och genetisk-demografiska data indikerar att den vitryska ethnien är mycket gammal» (Mikulitj, 2005, s. iii-iv). Hur gammal? En historisk atlas över Vitryssland som publicerades av exilvitryska forskare i Warszawa 2008 innehåller kartor för tiden 11 600-11 700 år sedan med en översikt över germaner, slaver, deras etnogenesis och bosättning som en logisk utveckling (Spirydonau, 2008, s. 10).

Journalisten Kjell Albin Abrahamson beskrev 1999 diskursen om »krivitjer, dregovitjer, radimetjer, volyner, podoler, polseser och så vidare» som "legender, gissningar, myter, spekulationer, lögner och förbannad dikt»(Abrahamson, 1999, s. 56). Oaktat hur det egentligen förhöll sig med den etnopolitiska situationen under 800talet blev denna mytiska förhistoria under nitton- och tjugohundratalen politiskt sprängstoff.

\section{Krivitjerna}

Av dessa halvmytiska folkstammar är det främst krivitjerna som kom att spela en viktig roll i den nationalitiska mytologin. Etnonymen krivitjer är förknippad med aktivisten Vatslau Lastouski (1883-1938), som introducerade sin "krivitjiska teori» 1910. Lastouski menade att krivitjerna (belarusierna/vitryssarna) var ett västligt folk, till skillnad från deras östliga grannfolk, då deras "antropologiska typ» i rasligt hänseende härstammade från arier och västeuropéer medan storryssar eller moskoviter till stor del utgörs av assimilerade mongoler och finsk-ugriska grupper (Lastouski, 1910 [1993]; Rudling, 2015, s. 118-119).

Under första världskriget publicerade Lastouski sina teorier med såväl finansiellt som logistiskt stöd av de tyska ockupationsmyndigheterna (Lastauski, 1919). Det var inte bara Berlin som såg den geopolitiska potentialen i Lastouskis krivitjiska teori som motvikt mot polskt och ryskt inflytande. På 1920-talet stödde det litauiska ministeriet för vitryska ärenden publiceringen av Vatslau Lastouskis Rysk-Krivitijiska (Vitryska) ordbok och fortfarande i mitten av 1930-talet utgavs hans historiska arbeten, såsom De vityska (krivitjiska) böckernas historia i Kaunas (Lastouski, 1924; Lastouski, 1936). Lastouski var inte utbildad historiker utan en ideolog som kryddade sin historia med spekulationer och rena fabrikationer. I tidsskriften Kryvitj, som finansierades av den litauiska regeringen, argumenterade han för att använda Kryvitjtja istället för Belarus', som han betraktade en term som påtvingats i samband med kristnandet (Łatyszonek, 2015, s. 122). Lastouski arresterades och sköts under Stalin, men den krivitjiska idén överlevde. Andra världskrigets vitryskspråkiga press citerade Lastouskis skrift Vad varje vitryss bör veta och framställde den vit-röd-vita färgkombinationen som den autentiskt "vitryskt-krivitjiska" (belaruski-kryivitji) (Sjkelonak, 1941; Ranitsa, 1944). 


\section{Abramtjyk och det Krivitjiska rådet}

Det i exilen marginaliserade BNR kom att slitas av fraktionsstrider. De sista resterna av dess verksamhet upphörde då dess siste och i det närmaste bortglömde ordförande Vasil Zacharka (1877-1943) dog i Prag den 14 mars 1943 (Hardzienka, 2009a, s. 19, 22). Den krivitjiska idén återupptogs efter kriget av en grupp aktivister runt Mikola Abramtjyk (1903-1970), aktiv i DP-lägret Osterhofen i Bayern. Abramtjyk, som under kriget arbetat som propagandist för de tyska ockupationsmyndigheterna, hävdade 1947 att Zacharka skulle ha utnämnt honom till sin efterträdare på sin dödsbädd, den 6 mars 1943 (Za voliu, 1951). »Återupprättandet» av BNR 1947 ger upphov till många frågor (Hardzienka \& Jurevitj, 2013, s. 9). Gruppen runt Abramtjyk var en annan än den som konstituerats 1918, och kallade sig dessutom kryvichi (krivitjer) och deras politiska grupp Kryvitskaja rada BNR (BNRs krivitjiska råd). Just namnfrågan skulle under 1947-1948 komma att bli ytterligt infekterad, och ledde till att en bitter splittring uppstod mellan två vitryska exilgrupper i de amerikanska och brittiska ockupationszonerna i det ockuperade Tyskland (Hardzienka, 2009b, s. 457-458). ${ }^{13}$ Dispyten gällde den här gången inte frågan om ledet -ryssland, utan ledet -rus', alltså identifieringen med det medeltida Rus' som sådant; Abramtjyks till stor del katolska krets sökte distansera sig från termerna Belarus' och belaruski, också därmed från arvet från Rus' som sådant (Kasiak, 1989, s. 314). De knöt istället an till Lastouskis etnonymer Kryvija och kryvitski och gav sina ungdomsorganisationer namn som Kryvitskae studentskae zhurtavan'ne (Krivitjiska studentföreningen) och Zhurtavan'ne kryvitskich skautau na tjuzjyne (Kryvitjiska scoutföreningen i utlandet). I november 1947 trycktes det första numret av gruppens tidning Batskausitjyna (Fosterlandet), 1947-1966 utgiven av Stanislau Stankevitj (1907-1980) (Hardzienka \& Jurevitj, 2013, s. 16). ${ }^{14}$ I Batskausjtjyna kan vi läsa om hur regionen och folket givits sitt namn. ${ }^{15}$

Efter att ha erövrat Vitryssland [Belarus'] förstod moskoviterna [maskal' - en milt pejorativ term] att det inte låg i deras intresse att kalla vitryssarna [belarusy] 'litsviner' [litsviny] (m.a.o. deras andra ursprungliga namn, vid sidan av krivitjer) eftersom det för alltid skulle påminna vårt folk om de tider då våra förfäder fann sig i en permanent kamp mot Moskva. Därför applicerade moskoviterna termen 'vitryssar' [belarusy] på vårt folk, medan namnet 'litsviner' attribuerades till litauerna. (Barsjtjeuskaja, 2005, s. 75$)^{16}$

\footnotetext{
${ }^{13}$ Om BTsR, se (Solov'iev, 1995).

${ }^{14}$ Batskausjtjyna, likt Abramtjyks BNR, var i hemlighet finansierad av CIA 1951-1960. De var båda del av projektet AEQUOR som syftade till att exploatera vitrysk nationalism för att försvaga Sovjetunionen (Research Aid, 2007, s. 3). Om Batskausjtjyna, se NARA, 1958, s. 195; Łatyszonek, 2015, s. 124.

${ }^{15}$ Om exilgruppernas verksamhet, se Prantjak, 1994, s. 59-65; Cummings, 2021, s. 176-194.

${ }^{16}$ Då Abramtjyks grupp var liten och av begränsad politisk användning tog CIA sin hand från gruppen och avbröt sitt operativa samarbete med BNR 1954. Dess finansiering av gruppen avbröts 1961 (NARA, 1956, s. 1; NARA, 1961).
} 
Så skarpa var motsättningarna att det i vissa fall kom till handgripligheter. I DP-lägret Michelsdorf i Bayern blev i maj 1948 vitryska scouter som bar en flagga med ordet Kryvija svårt misshandlade av aktivister tillhörande den vitryska kyrkokommittén och starka anhängare av termen Belarus' (Hardzienka, 2009b, s. 459). De huvudsakligen ortodoxa vitryska emigranterna förhöll sig negativt till namnet kryvitjer, som med tiden tappade i popularitet för att så småningom överges i tysthet. Det bestående minnet av termen är väl idag snarast att Abramtjyks grupp kom att benämnas »krivitjer» (Hardzienka, 2009a, s. 23). ${ }^{17}$

Abramtjyk insisterade på att "moskoviterna" utsatt hans nation för folkmord (Abramčyk, 1950; House Select Committee on Communist Aggression, 1954, s. 52-54). ${ }^{18} \mathrm{Om}$ ett folkmord begåtts mot det vitryska eller krivitjiska folket måste ju följaktligen ett sådant folk existera. I den politiska kampen om vem som har rätt att representera nationen uppstod två genompolitiserade historiografier; mot den sovjetvitryska traditionen står den långdistansnationalistiska som ömsesidigt fördömde varandra som folkmördare och »förfalskare» (Ivanov, 1980).

\section{Storlitauen}

Efter att kryvitjien huvudsakligen övergivits av Abramtjyks grupp dök en ytterligare rival upp bland etnonymerna. Under 1960- och 70-talen sökte delar av diasporan introducera neologismen "Storlitauen». Försöken att appropriera termen Litva associeras med den Chicago-baserade amatörhistorikern Vatslau Panutsevitj (19111991), som skrev böcker såsom Krivitjen-Litauen: En historia (1965) och gav ut tidsskriften Litva (Litauen) 1967-1973 (Panutsevitj, 1965). Etnonymen "storlitauisk» (vialikalitouski) är emellertid främst associerad med Jan Stankevitj (1891-1976), en annan aktivist i kretsen runt Abramtjyk. Stankevitj (1982), doktor i slavistisk vid Karlsuniversitet i Prag och i likhet med Abramtjyk romersk katolik, menade att namnet "Belarus» hade blivit påtvingat av Katarina II och därför utgjorde en kolonial rest. Istället satte han likhetstecken mellan det gamla Litauen och »de vitryska etniska territorierna». Oleg Łatyszonek betraktar »historikern Stankevitj som något av en nationell ideolog, då han var mycket mer intresserad av nationsbyggande än ett vetenskapligt sökande efter sanning» (Łatyszonek, 2015, s. 127). Lika engagerade som Lastouski och Abramtjyk varit för "sin» etnonym sökte Stankevitj outtröttligt introducera sitt Vialikalitva eller Storlitauen. Hans magnum opus, den år 1982

\footnotetext{
${ }^{17}$ Termen verkar ha fått en viss användning bland vissa ultranationalistiska grupper. Anti-Bolshevik Bloc of Nations, en extremhögergrupp ledd av den ukrainska Bandera-rörelsen, beskriver gruppen som "Kriviches (Byelorussians)", och det förekommer även i en del CIA-rapporter från de omedelbara efterkrigsåren (Declaration of the Anti-Bolshevik Block of Nations, 1946). Under det tidiga 1990-talets nationella väckelse sökte vissa grupper återintroducera termen Kryvija (Temper, 2012, s. 116-117; Kazakevich, 2006, s. 4-10; Babkou, 2005).

${ }^{18} \mathrm{Om}$ folkmordsretoriken i den vitryska nationalistiska diskursen, se Goujon, 1999; Weiss-Wendt, 2018, s. 43.
} 
postumt utgivna ordbok om 1305 sidor som publicerades av Lew Sapieha Greatlitvan (Byelorussian) Foundation bar titeln Vjalikalitouska-rasijski, eller Greatlitvan-Russian Dictionary. Neologismen "storlitauisk» (vialikalitouskı) åberopade historiska geografiska termer snarare än lingvistiskt-genetiskt ursprung (Stankevitj, 1982).

\section{Vad ska man kalla den nya staten på svenska?}

Vid självständighetens utropande år 1991 var benämningen av den nya staten som Vitryssland på svenska okontroversiellt, då det, till skillnad från det sovjetiska Bjeloeller Beloryssland knöt an till ett sedan länge etablerat, försovjetiskt namn. Samtidigt gav den nya geopolitiska situationen efter Sovjetunionens fall och uppkomsten av ett oavhängigt Vitryssland upphov till diskussioner om namnfrågan. "Det är fortfarande oklart om omvärlden kommer att anta det nya namnet Belarus eller fortsätta med gamla beteckningar", noterade en observatör i en av de första svenskspråkiga akademiska arbetena om det nu självständiga Vitryssland (Cutting, 1992, s. 188). Barbara Törnquist-Plewa, som 1997 publicerade det svenskspråkiga standardverket om Vitryssland, noterade hur "Det svenska namnet på Belarus, dvs. Vitryssland, är inte en helt korrekt översättning av den vitryska motsvarigheten. Den skulle säkerligen ogillas av de vitryska patrioterna, lika mycket som de ogillar den engelska benämningen 'Byelorussia'». Törnquist-Plewa betonar just skillnaden mellan Rus' och Ryssland, och att dessa är olika begrepp.

Detta vill de vitryska nationellt sinnade krafterna poängtera genom att föredra namnet Belarus eller White Ruthenia (på engelska) framför Byelorussia. Därför bör man egentligen plädera för att namnet Belarus' introduceras även i svenska språket. Då denna benämning emellertid ej är etablerad, särskilt vad gäller adjektiv avledda från detta egennamn (belarusisk? belaruthensk?) eller namn på befolkningen (belarusiner? belaruser? belaruthener?) så kommer jag i framställningen oftast att använda de traditionella benämningarna 'vitrysk,' 'vitryssar' etc. (Törnquist-Plewa, 1997, s. 17)

I sin populärvetenskapliga bok Vitryssland - 89 millimeter från Europa frågade sig 1999 journalisten Kjell Albin Abrahamson »om det finns något europeiskt land som haft så många inadekvata och parallella namn som detta kulturella gränsland» och om och när omvärlden kommer att acceptera Belarus i stället för Vitryssland: »Med det nya namnet markerar vitryssarna att de är en historisk del av det kievska Rus och inte av det moskovitiska Ryssland. Det är en viktig identifikationsmarkör och ett namnbyte som inte skulle gått igenom med dagens ryssvänlige president. Namnet 'vitryssar' är förvirrande och opraktiskt» ${ }^{19}$ (Abrahamson, 1999, s. 59).

Namnfrågan var ännu inte kontroversiell när Tobias Ljungvalls bok Kontroll: Rapport från Vitryssland publicerades av SILC - Svenskt internationellt liberalt

\footnotetext{
${ }^{19}$ Det att Ambrahamson insinuerade att Lukasjenkaregimen skulle motsätta sig ett svenskt namnbyte saknar stöd i källorna. "Ryssvänlig» eller ej, Lukasjenkaregimen har aldrig formellt motsatt sig Sveriges användning av exonym. Den har konsekvent brukat det officiella namnet Belarus'.
} 
centrum 2003 (Ljungvall, 2003). Kampanjen för ett namnbyte är av senare datum. Språkvetaren Ola Karlsson skriver i Språktidningen att "från 2009 och framåt har föreningen Sveriges belarusier och vissa svenska politiker och opinionsbildare förordat en svensk övergång till namnet Belarus» (Karlsson, 2020).

Emedan Lukasjenka valts på en plattform baserad på sovjetnostalgi och kamp mot korruptionen förändrades det politiska landskapet med Vladimir Putins makttillträde vid millennieskiftet (Rudling, 2011b). Under ett allt starkare tryck från ett alltmer aggressivt Ryssland kom Lukasjenka att betona nationella värden, statlighet och mobilisering runt fanan och landets institutioner. Nationella referenser har blivit en "skyddande sköld" mot en hotfull omvärld (Leshchenko, 2004, s. 346). En liknande utveckling ägde under samma tid rum i den nya växande vitryska diasporan, som från 2008 uttryckt synpunkter på sina adopterade staters bruk av exonymer för deras ursprungsland.

Att den självständiga staten officiellt benämner sig Respublika Belarus' kan och har anförts som argument mot etablerade exonymer i flera kontinentaleuropeiska stater.

I kraftmätningen mellan namnskick och politiska hänsyn har ofta de tidigare fått stå tillbaka för de senare. Namnkunniga svenska redaktörer och språkgranskare motsatte sig länge aktivisternas försök till namnbyte. Svenska Dagbladets språkkrönikör Bo Löfvendahl argumenterade 2013 för exonymernas existensberättigade, hur dessa är en självklar del av alla språk och oftast helt okontroversiella: "Om vi vill kunna tala om förhållandena $\mathrm{i}$ andra länder behövs exonymer, $\mathrm{i}$ vårt språk liksom andra språk - de förenklar uttalet och underlättar förståelsen» (Löfvendahl, 2013). Två år senare utvecklade Löfvendahl resonemanget:

Att ett land på andra språk har ett annat namn som skiljer sig från de inhemska är helt normalt. Sådana namn kallas för exonymer: Tyskland, Frankrike, Kanarieöarna. Orden belarusisk och belarusier har ytterst få belägg i svensk tidningstext, och orden är praktiskt taget okända för den genomsnittlige läsaren. De som vill etablera benämningen belarusisk har en lång resa framför sig. Och de behöver inse att inga argument slår ut redaktörernas krav på läsbarhet och tydlighet. (Löfvendahl, 2015)

Länge dominerade bruket av "Vitryssland» stort, även om "Belarus» ökade i användning. Runt 2010 utgjorde "Belarus» cirka fem procent av beläggen i mediatexter, en siffra som vuxit till över tio procent 2020 (Karlsson, 2020). Vid sidan av argumenten för klarhet och exonymers existensberättigande finns också en föreställning om suveränitet och vem som har "rätt» att styra över självständiga staters namnskick. Ola Karlsson noterar i Språktidningen "Att behålla gamla nationella exonymer är en stark tradition i väldigt många länder, och sådana namn brukar vi inte utmönstra utan synnerliga skäl. Att Vitryssland faktiskt har instiftat en lag som säger att andra nationer ska benämna nationen 'Republiken Belarus' är ingen sådant skäl ... någon rätt att styra över andra nationers namnskick har förstås inget land» (Karlsson, 2020). 


\section{Identitetspolitik och debatten kring "Vitryssland» i Sverige}

Törnquist-Plewa citerar lingvisterna Edward Sapris (1884-1939) och Benjamin Lee Whorfs (1897-1941) tes "att språket påverkar gruppens kollektiva medvetande och även beteende, då det fungerar som raster vid gruppens perception av världen» (Törnquist-Plewa, 1997, s. 13). Sedan millenieskiftet har vi sett identitetspolitikens genombrott i Sverige. Just föreställningen om språklig relativitet, alltså att språket styr tanken spelar en framträdande roll i identitetspolitik och woke-kultur, även om vi inte kan påvisa ett kulturellt samband mellan till exempel användandet av ett könsneutralt pronomen som "hen» och jämställdhet (Parkwall, 2021). Författaren Torbjörn Elensky noterar hur woke whar vuxit till att bli det amorfa begrepp det är idag. Från att ha handlat om de svartas egen uppmärksamhet på förtryck har det blivit ett uttryck för kamp mot alla slags orättvisor, och inte bara de faktiska, materiella och påtagliga, utan inte minst så kallade mikroaggressioner, alla sorters fobier, vithetskritik och annat som det väldigt ofta är väldigt svårt att definiera» (Elensky, 2021).

En del av aktivismen som omgärdat frågan om hur vårt grannland ska benämnas är färgad av post- eller antikoloniala tankefigurer. ${ }^{20}$ Där finns en underliggande strävan att utbilda eller uppfostra svenskar som saknar rätt förförståelse och därför "hamnat fel» i sina tolkningar av landets relation till "det ryska». En av de tongivande aktivisterna för en ändring av det svenska namnskicket är Martin Uggla i Östgruppen, en utbrytargrupp ur Svenska Freds- och Skiljedomsföreningen. Uggla är inte principiellt motståndare till exonymer: "Jag ser absolut en poäng i att använda exonymer. Men just exonymen Vitryssland är på grund av sitt efterled olycklig och leder till beklagliga missförstånd» (Uggla, 2013). Uggla menar att termen Vitryssland skulle vara "en oskön parallell till den politiska utvecklingen» och "avspeglar en i grunden storrysk föreställning om att det inte finns någon specifik belarusisk identitet och att belarusiskan bara skulle vara en rysk dialekt» (Uggla, 2014, s. 175). Referenser till kränkning och kolonialism framfördes som centrala bevekelsegrunder bakom kampanjen för namnbyte i Sverige: "Jag ser det inte som att jag representerar belarusierna, utan snarare solidariserar mig med dem i en fråga där jag dels förstår varför många av dem uppfattar 'Vitryssland' som kolonialt och kränkande, dels tror jag själv att många svenskar ibland hamnar fel i sina försök att förstå utvecklingen i landet på grund av att de tolkar den med utgångspunkt i dess relation till Ryssland och det ryska», argumenterade Uggla (2015).

\section{»Bruntyskar» och »vitfinnar»}

Den politiska atmosfären åren runt 2015 var laddad; den ryska invasionen av Ukraina, migrationskris, Brexit, Trump och Metoo-rörelsen ackompanjerades av en

\footnotetext{
${ }^{20}$ Med detta inte sagt att koloniala tolkningsmodeller inte är tillämpliga på Belarus/Vitryssland (Lewis, 2018).
} 
ofta skarpt polariserad retorik i press och sociala medier. Det är möjligt att tidsandan bidrog till det höga tonläge i vilken en del av debatten fördes (Oscarsson, Bergman, Bergström \& Hellström, 2021). En av de mest profilerade motståndarna till den traditionella svenska namnformen är översättaren Nils Håkansson. Håkanssons språkbruk är klätt $i$ en terminologi vi känner från identitetspolitiken, med ledord som vithet, respekt, kolonialism, kränkning och befrielse:

Det är inte i vitheten som problemet sitter. Vit är en fullgod översättning av det mångtydiga förledet $b e l$, som ingen riktigt vet vad det betyder i detta sammanhang - vit, klar, fri eller västlig. Problemet sitter i ordets efterled och sammanblandningen av två historiska och kulturella storheter - Ryssland och Rus. (Uggla, 2014, s. 173, citerar Nils Håkansson)

Under rubriken "Ned med Vitryssland!» argumenterade Håkansson i Upsala Nya Tidning:

I åratal nu har det gjorts ihärdiga försök att befria svenskan från detta ordet 'vitrysk' med alla dess obehagliga avledningar. Vad man istället ska säga är 'belarusisk,' 'Belarus' etc. Varför då? För att det heter så, ljushuvud. Alltså: 'rus' är inte detsamma som 'Ryssland' ('Vit' däremot kan funka för 'bel'.) Rus är benämning på ett större historiskt område som idag omfattar stora delar av Västra Ryssland, Ukraina, Belarus och Baltikum. Ryssland - det är något annat, det kom sedan. En visserligen haltande jämförelse kan göras mellan Germanien och alla de stater som utvecklades ur det området. Tänk er att man i USA skulle kalla oss svenskar för brown Germans, hur kul skulle det vara? Men det är ungefär vad vi gör när vi envisas med detta 'Vitryssland'. (Håkansson, 2015b)

På Sveriges Televisions webbsida utvecklade Håkanson tesen om svenska exonymen som en historisk oförrätt och namnet därtill "felaktigt»: "Misstaget är historiskt: senast på 1600-talet började svenskar efter tysk modell att tala om 'Vitryssland'. Vilket för övrigt är ett återkommande argument för att behålla namnformen: eftersom vi gjort fel så länge kan vi inte börjar göra rätt nu». Önskan att behålla det månghundraåriga lokala svenska namnskicket länkas till kolonialism och respektlöshet: „Ceylon ändrade 1972 sitt namn till Sri Lanka eftersom det gamla namnet ansågs vara en rest från ett kolonialt förflutet. Beslutet respekterades av världssamfundet. I Sverige möter man inte sitt grannland med samma respekt, trots att den belarusiska staten redan 1991 byte [sic!] ut det misshagliga 'Belorussija' mot just Belarus» (Håkanson, 2015a). I sociala medier förklarade Håkansson att "Belarusier blir kränkta av att vi säger Vitryssland. Ett skäl nog att lägga av» (Håkanson, 2015c).

Föreningen Sveriges Belarusier argumenterade att

Det har aldrig varit så viktigt för oss belarusier att det skulle heta just 'Belarus' som det varit viktigt att det inte skulle heta 'Vitryssland.' Vi har inget otalt med Ryssland och ryssar, men det är inte roligt att hela tiden bli misstagen för någon annan och associerad med saker du inte har någon relation till och inte kan avhjälpa. En studie vi genomförde i augusti 2010 har tydligt visat att svenskar associerar 'vitryssar' med Ryssland mer än något annat folk i Europa, och att de negativa fördomarna som 
tyvärr finns i Sverige om Ryssland tydligt spiller över på belarusier om de presenterar sig som 'vitryssar'. ${ }^{21}$

För att illustrera vad de menade var den svenska endoymens orimlighet åberopar Sveriges Belarusier det fiktiva ordet "vitfinne».

\section{SVENSK $\neq$ VITFINNE BELARUSIER $\neq$ VITRYSS}

Figur 3. Ill. 1. Sveriges Belarusier, http://sverigesbelarusier.se/belarus-vs-vitryssland?langswitch_ lang=sv (besökt 29 maj 2021).

Inom politiken vann denna aktivism gehör främst från riksdagens minsta parti Liberalerna, vars riksdagsledamot Maria Nilsson 2019 tog upp namnfrågan i riksdagen:

Den 15 oktober demonstrerade föreningen Sveriges Belarusier på Mynttorget i Stockholm mot att Utrikesdepartementet fortsätter att använda begreppet 'vitryssar' ett begrepp som många belarusier i Sverige upplever som mycket besvärande eftersom det skapar starka associationer till Ryssland och gör att belarusier i vardagen ständigt blir misstagna för ryssar. ... Den belarusiska diasporan har i åratal vädjat till regeringen att avveckla den missvisande och politiskt laddade beteckningen 'Vitryssland' och 'vitryssar' från det officiella svenska språkbruket och ersätta det med det mer politiskt neutrala och i förhållande till landets officiella namn korrekta 'Belarus' och 'belarusier'». (Nilsson, 2019)

Den svenska regeringens formella namnbyte kom den 24 november 2019. "Det är ett erkännande av det belarusiska civilsamhället och folket som länge velat framhäva sitt lands nationella identitet och suveränitet», argumenterade utrikesminister Ann Linde. "Utrikesdepartementet överger därmed en benämning som kan associeras med Ryssland eftersom ändelsen 'rus' inte syftar på Ryssland", menade hon (Svenska Dagbladet, 2019). Utrikesministern förklarade inte på vilket sätt namnändringen skulle reflektera den belarusiska/vitryska folkviljan och preciserade inte hur det svenska bytet från exonym till endonym skulle stärka civilsamhället.

Ola Karlsson i Språktidningen invände att »den politiska ledningen på UD är knappast en språklig normauktoritet, och beslutet fattades utan språkliga avvägningar». Karlsson menade att

begrepp som Rus, Rusland och Rutenien har haft olika innebörd genom historien. Så de etymologiska argumenten får sägas vara mycket tveksamma redan i ryskan och vitryskan, och knappast heller relevant för exonymstavningar på andra språk. ... Etymologiskt

\footnotetext{
${ }^{21}$ Organisationen grundades 2009 och saknar verklig huvudman. Dess adress går till en privatlägenhet. https://www.bolagsfakta.se/8024492129-SVERIGES_BELARUSIER Dess publika Facebook-sida gillas i skrivande stund av 337 personer och följs av 406 (Sveriges Belarusier, n.d.). Utsagan att Belarus/Vitryssland skulle vara i avsaknad av relation till Ryssland och ryssar är diskutabel, då båda republikerna till 1991 var del av samma statsbildning och Belarus 1996 ingått ett nytt unionsavtal med Ryssland (Marples, 1999, s. 112-118).
} 
finns alltså inte mycket att invända mot Vitryssland. Man kan med fog påstå att Belarus betyder just 'Vitryssland,' och motsvarande namnform används fortfarande i ett stort antal länder i världen. (Karlsson, 2020)

Karlsson närmar sig det som är kärnan i diskussionen:

Föreställningen om att det sker en sammanblandning mellan länderna gör att vitryssar ofta känner sig illa till mods. Det är i sig ett relevant argument. Vi vet förvisso inte hur många som känner så. Men av allt att döma är den känslan utbredd eftersom den hänger intimt samman med en vilja till politisk självständighet gentemot Ryssland. Och den självständigheten är lite av kärnan i hela Belarusfrågan, oavsett vilka argument som används. Denna politiska vilja har ofta kommit att förknippas med oppositionella i Vitryssland, vilket möjligen kan förklara varför det finns så många Belarusanhängare bland svenska politiker och kulturskribenter. (Karlsson, 2020)

Språkvetarnas ord vägde i slutändan lätt mot politiken. Namnbytet handlade, till syvende och sist, inte om språkliga normer utan om storpolitik. UDs namnbyte kom att bli normerande i Sverige. En stor del av massmedia följde nu efter och övergav den svenska namnformen. Svenska Dagbladets Lena Lind Palicki angav följande motivering till namnbytet:

Nationsnamnet Belarus har varit en het potatis under många år, och i juni i år [2020] beslutade sig flera medier, bland annat Svenska Dagbladet, tillsammans med Språkrådet för ett byte. Bytet hänger ihop med politiska ställningstaganden. Belarus vill visa självständighet gentemot Ryssland och frigöra sig från oönskade historiska band. Vitryssland har använts i svenskan sedan 1600-talet, men under de senaste åren har namnformerna förekommit parallellt, vilket onekligen har väckt en del förvirring. Belarus är numera den officiella svenska formen i regeringen, i EU och andra mellanstatliga sammanhang - och i medierna. Politik har alltid en språklig dimension. Och språk har ofta en politisk. (Palicki, 2020)

\section{Hvidløg og løg}

Svenska Dagbladets motivering liknade den aktivisterna torgfört under ett decennium: "namnet ger ändå en icke önskvärd historisk koppling till Ryssland» (Berglund, 2020). De svenska myndigheternas beslut ska ses som del av en större process, där liknande rörelser ägde rum i andra EU-länder. I mars 2020 ändrade Danmark formellt benämningen från Hviderusland till Belarus, efter en diskussion med betydande likheter med den som förts i Sverige:

Men gör det nogen forskel på, om det hedder Hviderusland eller Belarus? - Hvis nogen spørger, om der er forskel på Hviderusland og Rusland, så spørger jeg tilbage; er der forskel på hvidløg og løg? Selvfølgelig er der forskel, det har en kæmpe betydning. 'Hviderusland' lyder forkert i manges ører, fordi man automatisk kommer til at tænke på det som et lille territorie, der hører under Rusland. - Men vi er 100 procent selvstændige. Og det er virkelig vigtigt for os, at vi bliver hørt. (Anastasia Valentin Rasmussen, styrelsemedlem i organisationen Talaka - Venner af Belarus i Danmark citerad i Christiansen, 2021) 
Diskursen är bekant: likt lök och vitlök utgör olika arter, utgör Russland och Belarus fundamentalt skilda väsen. Namnbytet knyts till nystart, palingenesi och återfödelse.

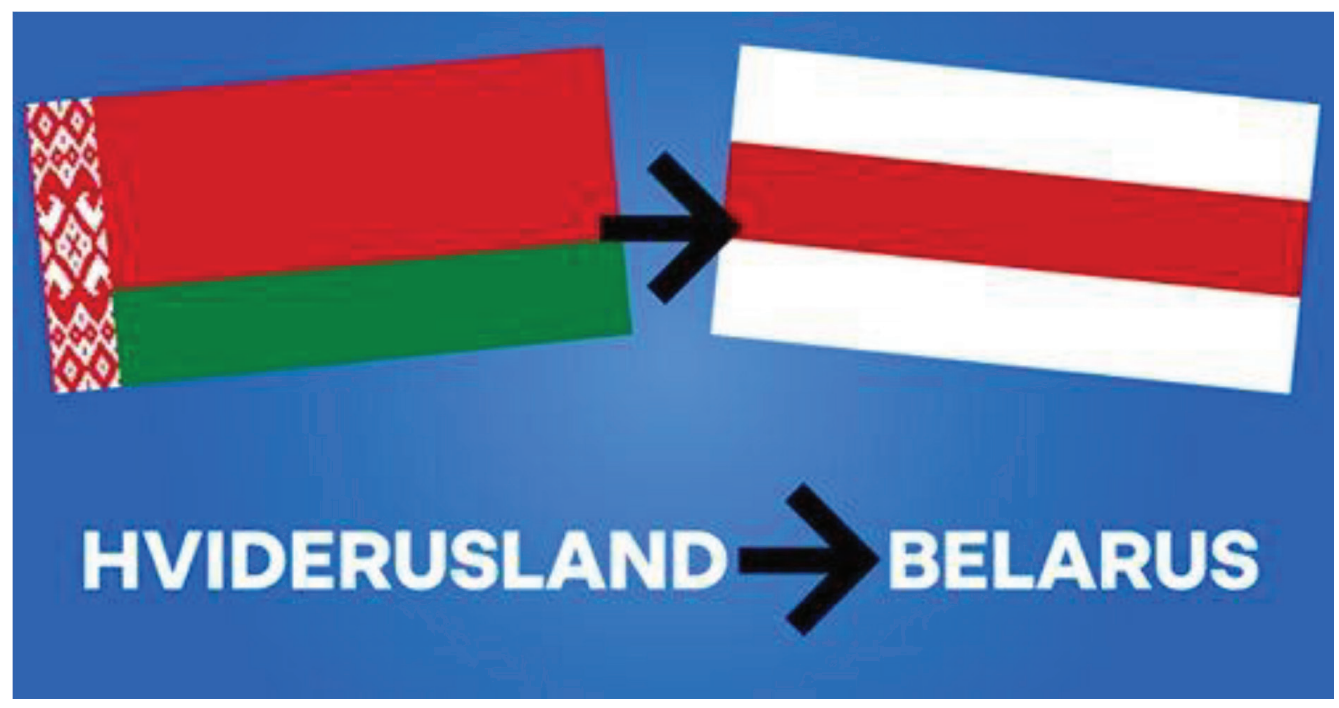

Figur 4. Danmarks Radios illustration levandegör de ofta implicita undertonerna bakom namnändringen, där namnbytet associeras med större förändringar. Hviderusland länkas till Lukasjenkaregimens neosovjetiska attribut, Belarus till 1918/1991 års statsflagga, en symbol för oppositionen. Illustration till Christiansen "Hviderusland bliver til Belarus i Udenrigsministeriet», en kronik på nettsidan til Danmarks Radio.

I december 2020 tog Tyskland ett liknande beslut, efter en rekommendation från en belarusisk-tysk historikerkommission. Motiveringen var även här explicit politisk:

Vi rekommenderar att på tyska istället för Weißrussland som landsnamn använda den officiella beteckningen Belarus och som adjektiv belarusisch. På så sätt blir det klart, att det handlar om Republiken Belarus som en suverän stat som inte är del av Ryssland. (Belarusisch-Deutsche Geschichtskommission, 2020)

I det tyska fallet föreligger ytterligare komplicerande aspekter. Tyskan har i Weißruthenien en endogen term som språkligt skulle kunna tillfredsställa såväl diasporans önskan att maximera avståndet till Ryssland samtidigt som den är förenlig med tyska uttalsregler, med djupa historiska rötter i tysk namntradition. Givet Tysklands nyare historia ansågs detta emellertid politiskt olämpligt:

Det ursprungliga namnet på detta landområde var på tyska Weißruthenien. 'Bela' syftar på färgen vit. Begreppet Ruthenien hänvisade till de områden i Kyiv Rus', som hörde till Storfurstendömet Litauen fram till 1772. Vi rekommenderar att även fortsättningsvis enbart använda beteckningen Weißruthenien historiskt, eftersom den användes som kolonial projektion av de tyska ockupationsregimerna i två världskrig. (Bohn, 2020) 


\section{Slutsatser}

Ett ledmotiv som ofta återkommit har varit att de svenska - och germanska exonymerna skulle vidmakthålla oönskade koppningar och historiska band. En fråga som inte klart besvarats är: för vem är dessa historiska band och historiska kopplingar oönskade? Hur representativ organisationen Sveriges Belarusier är är oklart.Vi saknar helt enkelt data som stödjer antagandet att belarusier/vitryssar skulle vara kränkta av att det på norska, litauiska, nederländska och finska används exogena namn på landet. Uppfattningen att banden till Ryssland skulle vara "oönskade», att belarusier/ vitryssar "inte har någon relation till» Ryssland, att det är en artskillnad mellan de två, likt vitlök och lök, att de nord- och västgermanska språkens exonymer skulle utgöra absurditeter likt "vitfinnar", "brown Germans» utan historisk kontext och rationellt sammanhang kan med fog problematiseras mot bakgrund av de data vi har att tillgå.

Oberoende undersökningar tyder på en stark nationalstolthet i republiken. 78 procent av tillfrågade säger sig vara stolta över att vara belarusier/vitryssar, samtidigt som nästan 75 procent anger att de känner sig mer närbesläktade med ryssar än "européer» (Marples, 2014, s. 362). Även om den pro-ryska inriktningen bland tillfrågade belarusier/vitryssar minskat något sedan protesterna 2020 är den pro-ryska inställningen mycket djupt rotad i det belarusiska samhället. ${ }^{22}$ Undersökningar som gjorts över åren visar samstämmigt att det sovjetiska förflutna inte uppfattas som en kolonisation och att det ryska språket och kulturen inte ses som främmande (Ioffe, 2008, s. 88; Ioffe, 2014, s. 26). Efter trettio år av självständighet är ryskans ställning som det helt dominerande språket i Republiken Belarus ohotad samtidigt som de som talar belarusiska/vitryska till vardags utgör en befolkningsandel på mellan två och sju procent (Ioffe, 2008, s. 7, 29; Ioffe, 2014, s. 18). Geografen Grigory Ioffe har sökt problematisera den nationella diskurs, dominant inom diasporan, där

Det centrala budskapet är att vitryssar är ättlingar till Storfurstendömet Litauen och att rysk kolonialism förhindrar dem från att återupptäcka sina sanna, europeiska jag. Emedan denna idé har sin egen nisch i den allmänna diskursen om vitrysk identitet, identifierar sig inte mer än 20 procent (i bästa fall!) av vitryssar som lever i Republiken Belarus med denna nisch. (Ioffe, 2008, s. xiv)

Det falsifierade presidentvalet 2020 ledde till protester utan motstycke i landets historia. Dessa följdes av en våg av exempellös politisk repression. I skrivande stund håller myndigheterna, enligt människorättsorganisationen Vjasna, 833 politiska fångar; rapporter om misshandel och tortyr är många (Viasna, human rights center, 2021). Samtidigt bevittnar vi framväxten av ett civilsamhälle med alternativa referenser,

\footnotetext{
${ }^{22}$ För en god översikt om attityder i identitetsfrågor under 00-talet se Ioffe, 2008, s. 193-229. Enligt en opinionsundersökning från Chatham House från april 2021 har $79 \%$ av de tillfrågade belarusierna/vitryssararna en positiv inställning till Ryssland och betraktar ryssar den grupp de anser sig stå närmast "andligt, mentalt eller kulturellt» (Astapenia, 2021, s. 16). Tack till Oleg Manaev för dessa data.
} 
symboler och ideal. Svenska Dagbladets veteranreporter Jan Blomgren skrev våren 2021 om "det sedan i somras politiskt pånyttfödda Belarus» (Blomgren, 2021).

Fallen Kampuchea, Zaïre och eSwani skulle kunna anföras till stöd för uppfattningen att det kan finnas fog för viss konservatism och kontinuitet i namnfrågan. Diasporaaktivister har sedan 1940-talet torgfört tre alternativ till den svenska namnformen, Sovjetunionen ytterligare två. Inget annat modernt europeiskt nationsprojekt har på svenska haft en sådan mångfald av namn - samtidigt som Republiken Belarus sannolikt är det grannland svensken i gemen vet minst om. ${ }^{23}$

Hos aktivisterna som drivit frågan om namnändring förnimmer man en önskan att höja landets status och profil, en slags re-branding. Som en röd tråd bakom dessa skymtar en outtalad vilja att maximera avståndet till Ryssland och orientera landet mot den atlantiska världen, en önskan om pånyttfödelse, palingesis. Kampanjen för namnändring har haft en implicit tendens att associera termen "Vitryssland» med det sovjetiska arvet och/eller Lukasjenkaregimen. Ändringen av namnskicket i de germanska språken ses som ett steg i en geopolitisk omorientering, knuten till förnyelse, nystart och förändring. Den är knuten till implicita eller explicita förhoppningar om palingenesi genom nationell pånyttfödelse, och att Belarus skulle kunna "återvända» till Europa och möjligen betraktas, som en analytiker uttryckt det, som "en fjärde baltisk stat» (Kott, 2015).

En viss aktivism kan även skönjas bakom det svenska UDs namnbyte, även om denna förefaller mer baserad på önskan om demokratisering, rättssäkerhet, rättsstatlighet och mänskliga rättigheter för landets medborgare. Huruvida ett nytt namn kommer att påverka vår syn på Belarus/Vitryssland, eller dess geopolitiska position i Europa återstår att se.

\section{Om artikeln}

Författaren vill uttrycka sin uppskattning för kommentarer och kritisk läsning av Kristian Gerner, Per-Arne Bodin och två anonyma recensenter. Tack också till Jared McBride för att generöst delat med sig av källmaterial och till Salomon Schulman och Jonas Vasur för vittra inspel om exonymer på jiddisch och estniska.

\section{Referenser}

Abrahamson, K. A. (1999). Vitryssland: 89 millimeter från Europa. Fischer \& Co.

Abramčyk, M. (1950). I accuse the Kremlin of genocide of my nation: Based on the secret documents of the Military persecutors and N.K. V.D. of the U.S.S.R. Byelorussian Alliance in Canada.

\footnotetext{
${ }^{23}$ Huruvida ett namn i sig påverkar kännedomen eller intresset för ett land kan ifrågasättas. Belarus är det land i Europa minst amerikaner hört talas om. Trots att amerikanska media sedan 30 år använt "Belarus» för statsbildningen uppgav 38\% av amerikaner tillfrågade av YouGov i oktober 2020 att de aldrig hört talas om landet; endast mikrostaterna San Marino och Andorra var mer okända (Smith, 2020).
} 
Ackermann, F. (2010). Palimpsest Grodno: Nationalisierung, Nivellierung und Sowjetisierung einer mitteleuropäischen Stadt 1919-1991. Harrassowitz Verlag.

Aleksejeva, T. I. (1973). Etnogenez vostotjnych slavjan. MGU.

Arlau, U. \& Sahanovich, H. (2002). Dzesjats' vjakou belaruskaj historyi (862-1918): Padzei. Daty. Iljustratssyi. Nasha Budutjynja.

Astapenia, R. (2021). Vzglad belorusov na polititjeskij krizis: Rezul'taty sotsionlogitjesjogo oprosa, provedennogo s 20 po 30 aprelja 2021 goda. Chatham House. https:/www.chathamhouse.org/sites/default/files/202106/2021-06-14-belarusians-views-political-crisis-russian.pdf

Astapova, A. (2018). How to pronounce 'Belarusian'?: Negotiating identity through naming. I Polese, A., Morris, J. Pawłusz, E. \& Seliverstova, O. (red.), Identity and national building in everyday post-socialist life (s. 131-145). Routledge.

Babkou, I. (2005). Henealohija belaruskaj idei. ARCHE 28(3), 136-165.

Barsjtjeuskaja, N. (2005). The way Belarusian emigration treats ethnographic borders of Belarus. I S. Janovitj (red.), Annus Albaruthenicus 2005/Hod belaruski 2005, 6 (s. 65-82). Villa Sokrates.

Belarusisch-Deutsche Geschichtskommission. (2020). Empfelungen zur Schreibweise von Belarus in deutschsprachigen Texten. https://geschichte-historyja.org/de/aktuelles/empfehlungen-zur-schreibweisevon-belarus-in-deutschsprachigen-texten/

Bely,A. (2000). Chronika »Belaj Rusi»/Chronicon Russiae Albae:Narys historyj adnoi heahrafitjnajnazvy. Entsyklapedyks.

Bemporad, E. (2013). Becoming Soviet fews: The Bolshevik experiment in Minsk. Indiana University Press.

Berglund, T. (2020, 21. juni). Kvalitetsspalten: Nu heter landet Belarus även i vår tidning. Svenska Dagbladet.

Blomgren, J. (2021, 29. maj). Belarus är Putins sista gräns mot västvärlden. Svenska Dagbladet.

Bodin, P.-A. (2006). Ryssland och Europa: En kulturhistorisk studie. Natur och Kultur.

Bohn, T. M. (2008). Minsk - Musterstadt des Sozialismus: Stadtplanung und Urbanisierung in der Sowjetunion nach 1945. Böhlau.

Bohn, T. M. (2020). Die Republik Belarus in deutschsprachigen Texten. https://geschichte-historyja.org/site/ assets/files/1046/200715_pressemitteilung_geschichtskommission_by_de.pdf

Bolagsfakta.se. (n.d) https://www.bolagsfakta.se/8024492129-SVERIGES_BELARUSIER

Brandt Larsen, R. (2017). Competing historical narratives in Belarusian textbooks. I B. Törnquist-Plewa, N. Bernsand \& M. Svensson La Rosa (red.), In search of transcultural memory in Europe (s. 107-116). Centre for European Studies at Lund University.

Christiansen, R. (2021, 18. mars). Hviderusland bliver til Belarus i Udenrigsministeriet: "En fantastisk nyhed». Danmarks Radio. https://www.dr.dk/nyheder/udland/hviderusland-bliver-til-belarus-i-udenrigsministeriet-en-fantastisk-nyhed

Cummings, R. H. (2021). Cold War frequencies: CIA clandestine broadcasting to the Soviet Union and Eastern Europe. McFarland.

Cutting, M. (1992). Vitryssland. I S. Gustavsson \& I. Svanberg (red.), Gamla folk och nya stater: Det upplösta sovjetimperiet (s. 188-204). Gidlunds.

Daukšytė, L. (red.). (2010). The borders of Lithuania: The history of a millennium. Baltos Lankos.

Declaration of the Anti-Bolshevik Block of Nations. (1946, 25. maj). Memorandum of the Anti-Bolshevik Block of Nations, NARA, RG 319, Records of the Army Staff, Records of the Assistance Chief of Staff, G-2 (Intelligence). Formerly Top Secret Intelligence Documents, 1943-1959, (Special Distribution (SD) and Top Secret Control (TSCJ), ID 925389 thru ID 925392, Box No. 23.

Elensky, T. (2021, 18. maj). "Woke»-väckelsen möter motstånd. Svenska Dagbladet.

Gerner, K. (2021). Spor o Rusi - tysjatjeletnjaja istorija. I A. E. Mankov \& M. O. Dubovitskaja (red.), $S$ ljubovju $k$ nauke. Moskva.

Goujon, A. (1999). 'Genozid': A rallying cry in Belarus. A rhetoric analysis of Some Belarusian nationalist texts. Fournal of Genocide Research, 1(3), 353-366.

Hardzienka, A. (2009a). Belaruski kanhresavy kamitet Ameryki (BKKA.) Belaruski instytut navuki j mastatstva.

Hardzienka, A. (2009b). Palitytjny raskol na belaruskaj emigratsyji u 1940-ia h. Belaruski histarytjny Ahljad, $16(2), 452-475$.

Hardzienka, N. \& Jurevitj, L. (2013). Rada BNR (1947-1970): Padzej. Dakumenty. Asoby. Knihazbor.

Harrison, D. (2020, 6. september). Roslagen har gett oss namnet Belarus. Svenska Dagbladet.

House Select Committee on Communist Aggression. (1954). Investigation of Communist Takeover and Occupation of the Non-Russian Nations of the U.S.S.R.: Hearings before the Select Committee of Communist Aggression, House of Representatives. July 1, 1954, Munich, Germany, Testimony of Mikola Abramtschik, (s. 52-54). US Government Printing Office. 
Håkanson, N. (2015a, 14. oktober). "Det heter Belarus, inget annat». SVT.se. https://www.svt.se/opinion/ oversattare-om-belarus

Håkanson, N. (2015b, 9. oktober). Ned med Vitryssland! Upsala Nya Tidning.

Håkanson, N. (2015c, 9. oktober). Till författaren, Facebook. https://www.facebook.com/stefan.eriksson.771? fref $=$ ts

Ioffe, G. (2008). Understanding Belarus and how western foreign policy misses the mark. Rowman \& Littlefield.

Ioffe, G. (2014). Reassessing Lukashenka: Belarus in cultural and geopolitical context. Palgrave MacMillan.

Ivanov, N. L. (1980). Kritika falsifikatsii istorii sotstialistitjeskogo stroitel'stva v BSSR (1921-1937 gg.). Navuka i technika.

Karlsson, K.-G. (1996). Vitryssland: Historia. I C. Engström (red.), Nationalencyklopedin, tjugonde bandet (s. 4). Bokförlaget Bra Böcker.

Karlsson, O. (2020). Vitryssland eller Belarus. Språktidningen (4). https://spraktidningen.se/artiklar/2020/04/ vitryssland-eller-belarus

Kasiak, I. (1989). Byelorussia: Historical outline. Historical materials collected, reviewed and prepared for publication by Ivan Kasiak. (overs. C. A. Manning). Byelorussian Central Council.

Kazakevich, A. (2006). Karotkaja henealohiia kryuskae idei. Palitytjnaja sfera (6), 4-10.

Kotljarchuk, A. (2004). The tradition of Belarusian statehood: Conflicts about the past of Belarus. I E. Rindzevičiute (red.), Contemporary change in Belarus (=Baltic and East European Studies, no. 2). (s. 41-72). BEEGS.

Kotljarchuk, A. (2007). Ruthenian Protestants of the Grand Duchy of Lithuania and their relationship with orthodoxy, 1569-1767. Lithuanian Historical Studies, 12, 41-62.

Kott, M. (2015). The rise and fall of Belarusian nationalism, 1906-1931 [Bokrecesion]. Fournal of Baltic Studies, 46(3), 414-416.

Kronsteiner, O. (1974). Die slowenischen Namen Kärntens in Geschichte und Gegenwart. Österreichische Namenforschung, Sonderreihe 1, 1-55.

Lastouski, V. (1910) [1993]. Karotkaja historyja Belarusi: z 40 rysunkami. Drukarnja Martsina Kuchty Universitetskae.

Łastouski, W. [Lastouski, V.] (1919). Białaruski Kalendar Swajak na 1919 hod. Zur Verstreitung im Gebiet des Oberbefehlhaber Ost. Bücherdrückamt Ds. Ost. Wydawiectwo W. Łastouskaho, Drukarnia M. Kuchty.

Lastouski, V. (1924). Padrutjny Rasiiska-Kryuski (Belaruski) Slounik. Vydan'ne Ministerstva Belaruskich Sprau u Litve.

Lastouski, V [Lastaskis, V.] (1936). Historyja Belaruskaj (kryuskaj) knihi: Sproba pajas'nitsel'naj knihopisi ad kantsa X da patjatku XIX stahodz'dzja/V.Lastaskis, Gudu knygos istorija, aiskinamosios bibliografijos bandimas nuo X smitmecio galo ligi XIX simtmecio pradzios. Drukanena Sakalouskaha.

Łatyszonek, O. (2006). Od Rusinów do Białorusinów u źródeł białoruskiej idei narodowej. Wydawictwo Uniwersytetu w Białymstoku.

Łatyszonek, O. (2015). Belarusian historians in exile: New circumstances, old problems. I M. Zadencka, A. Plakans \& A. Lawaty (red.), East and Central European history writing in exile 1939-1989 (s. 120-130). Brill.

Leshchenko, N. (2004). A fine instrument: Two nation-building strategies in post-Soviet Belarus. Nations and Nationalism, 10(3), 333-352.

Lewis, S. (2018). The 'partisan republic': Colonial myths and memory wars in Belarus. IJ. Fedor, M. Kangaspuro, J. Lassila \& T. Zhurzhenko (red.), War and memory in Russia, Ukraine, and Belarus (s. 371-396). Palgrave.

Ljungvall, T. (2003). Kontroll: Rapport från Vitryssland. Silc förlag.

Löfvendahl, B. (2013, 3. maj). Utländskt på svenska. Svenska Dagbladet.

Löfvendahl, B. (2015, 9. oktober). Aleksijevitj lär fortsätta vara vitrysk i Sverige. Svenska Dagbladet.

Magnus, O. (2001 [1555]). Historia om de nordiska folken. Gidlunds.

Magocsi, P. R. (1983). Galicia: A historical survey and bibliographic guide. University of Toronto Press.

Malenkov, G. (1974) [1953]. SUKP(b):s Centralkommittés verksamhetsberättelse vid 19:e partikongressen, 5 oktober 1952, i Dokument från SUKP(b):s 19:e partikongress (=Erfarenheter ur arbetarrörelsens kamp 2). Ordfront.

Marková, A. (2016). Sjljach da savetskaj natsyji: Palityka belarusizatsyji, 1924-1929. Belaruski histarytjny ahliad. Marples, D. R. (1999). Belarus: A denationalized nation. Harwood Academic Publishers.

Marples, D. R. (2014). 'Our glorious past': Lukashenka's Belarus and the great patriotic war. ibidem-Verlag.

Michaluk, D. (2010). Białoruska Republika Ludowa 1918-1920: U podstaw białoruskiej państwowości. Wydawnictwo naukowe uniwersytetu Mikołaja Kopernika. 
Mikulitj, A. (2005). Belarusy u henethnaj prastory: Antrapalohiia etnasu. Technalohija.

NARA. (1956). MEMORANDUM FOR THE RECORD: SUBJECT: Planning Conference with M. Abramchik and B. Ragula of the BNR from 10-14 September 1956, s. 1, Boris Ragula Name File, no. 2 of 2, RC Box 105, Vol, 2, Entry ZZ-19, RC 230/86/24/01, National Archives Records Administreation (härefter NARA), College Park, MD, USA https://www.cia.gov/readingroom/docs/RAGULA $\% 2 \mathrm{C} \% 20$ BORIS\%20\%20\%20VOL.\%202_0103.pdf

NARA. (1958). AEQUOR, Renewal (FY 1959), 17 Nov. 58, AEQUOR, Vol. 01, Entry ZZ-19, RC Box 007, RC 230/86/25/01, NARA, College Park, MD. vol. 3_0039.pdf, https://www.cia.gov/readingroom/docs/ AEQUOR\%20\%20\%20VOL.\%203_0039.pdf

NARA. (1961). Chief of Station TO: Chief, WE, SUBJECT: REDWOOD AECAMBISTA AEQUOR Meeting with AECAMBISTA/4, Dec. 4, 1961, Mikola Ambramtchik Name File, no. 2 of 2. Entry ZZ-19, RC Box 001, RC 230/86/21/07, NARA, College Park, MD.

NARA. (2007). Research Aid: Cryptonyms and Terms in Declassified CIA Files Nazi War Crimes and Japanese Imperial Government Records Disclosure Acts, June 2007, NARA, College Park, MD. https://www. archives.gov/files/iwg/declassified-records/rg-263-cia-records/second-release-lexicon.pdf

Niendorf, M. (2006). Das Großfürstentum Litauen: Studien zur Nationsbildung in der Frühen Neuzeit (15691795). Harrasowitz Verlag.

Nilsson, M. (2019). Användandet av namnet Belarus. Skriftlig fråga 2019/20:316 av Maria Nilsson (L). https:/www.riksdagen.se/sv/dokument-lagar/dokument/skriftlig-fraga/anvandandet-av-namnet-belarus_ H711316

Oscarsson, H. E., Bergman, T. Bergström, A. \& Hellström, J. (red.) (2021). Demokratirådets rapport 2021: Polarisering $i$ Sverige. SNS förlag.

Palicki, L. L. (2020, 25. augusti). Stavning språkligt sprängstoff i Belarus. Svenska Dagbladet.

Panutsevitj, V. (1965). Z history Belarusi: abo Kryvitjtjyny-Litvy. Belaruskaja vydavetskaja sjabrynja.

Parkvall, M. (2021, 15. mars). "Hen»-kulturer är inte mer jämställda. Svenska Dagbladet.

Poesche, T. (1878). Die Arier: Ein Beitrag zur historischen Anthropologie. Herrman Costenoble.

Prantjak, L. (1994). Belaruskaja Ameryka. Polymja.

Ranitsa: Belaruskaja tydnevaja hazeta u Njametjtjyne. (1942, 15 mars). Recension av Peter Schreiber, Zur politischen Entwicklung des Weißrussentums.

Ranitsa: Belaruskaja tydnevaja hazeta u Njametjtyne. (1943, 12. december). Die rassische Bedeutung der Volksbeziechnung 'weißrussisch'.

Ranitsa: Belaruskaja tydnevaja hazeta u Njametjtjyne. (1944, 19. november). Nasjyja natsyjanal'nyja emblemy.

Ranitsa: Belaruskaja tydnevaja hazeta u Njametjtjyne. (1945, 31. Januari). s. 3.

Rudling, O. (2017). The cult of the Balts: Mythological impulses and neo-pagan practices in the touristic clubs of the Lithuanian SSR of the 1960s and 1970s. Region: Regional Studies of Russia, Eastern Europe, and Central Asia, 6(1), 87-108.

Rudling, P. A. (2011a). 'An entirely different culture and an alien race': Scandinavian Ukrainian encounters on the Canadian prairies 1910-1940. Scandinavian-Canadian Studies/Études scandinaves au Canada, 20, 26-51.

Rudling, P. A. (2011b). Lukashenka and the 'red-browns': National ideology, commemoration of the past, and political belonging. Forum für Osteuropäische Ideen- und Zeitgeschichte, 15, 95-125.

Rudling, P. A. (2015). The beginnings of modern Belarus: Identity, nation, and politics in a European borderland. The fournal of Belarusian Studies, 7(3), 115-127.

Ryzy-Ryski, U. (1960). Origin of Whiteruthenia or 'Biełarus'. International Institute of Byelorussian Studies.

Seeger, G., Höppner, W., Sommer, R., Möchel, G., Bielfeldt, H. H., Reimann, G. \& Dippel, P. G. (red.). (1955). Belorussische SSR. Grosse Sowjet-Enzyklopedie, Reihe Länder der Erde 18. Verlag Kultur und Fortschritt.

Sehn, A. (1994). Etniska minoriteter i Polen i svenska diplomatrapporter 1918-1939. Del 2. Acta SuecoPolonica 3, Uppsala universitet, 141-182.

Siebert, D. (1998). Bäuerliche Alltagsstrategien in der belarussischen SSR (1921-1941): Die Zerstörung patriarchalischer Familienwirtschaft (=Quellen und Studien zur Geschichte des östlichen Europas, Band 52). Franz Steiner.

Sjirjajev, E. E. (1991). Rus'Belaja, Rus Chernaja i litva v kartach. Navuka i technika.

Sjkelonak, M. (1941, 10, 20, 30 juli, 10. augusti, 20 september). Belarus-Litva-Kryvija, Ranitsa.

Sloin, A. (2017) The fewish revolution in Belorussia: Economy, race, and Bolshevik power. Indiana University Press.

Smith, M. (2020). What countries do American like most? Yougov.org. http://today.yougov.com/topics/travel/ articles-reports/2020/10/26/what-countries-do-americans-most 
Solov'jev, A. K. (1995). Belorusskaja Tsentral'naja Rada: sozdanije, dejatel'nost', krach. Navuka i technika.

Spirydonau, M. F. (2008). Ustup. I P. Kazanetski \& V. Mikaleevich (red.). Historytjny Atlas Belarusi. Tom 1: Belarus' ad strazjytnych tjasou da kantsa XVIII st. (s. 6-28). Stowarzyszenie Wschodnioeuropejskie Centrum Demokratyczne.

Stalin, J. V. (1952). Verksamhetsberättelse på sjuttonde partikongressen om SUKP(b):s centralkommitténs arbete den 26 januari 1934. I J. V. Stalin, Leninismens problem (s. 663-745). Förlaget för litteratur på främmande språk.

Stalin, J. V. (1954). The political tasks of the university of the peoples of the East. I J. V. Stalin, Works, Vol. 7 (s. 135-154). Foreign Languages Publishing House.

Stankevitj, J. (1982). Belorussko-russkij (Velikolitovsko-russkij) Slovar') Slovar'/Belaruska-rasijski (Vjalikalitouskarasijski) Slounik/Byelorussian-Russia (Greatlitvan-Russian) Dictionary. Lew Sapieha Greatlitvan (Byelorussian) Foundation.

Svenska Dagbladet. (2019, 25 november). Regeringen: Vitryssland blir Belarus.

Sveriges Belarusier.(n.d.).Belarus vs.Vitryssland.http://sverigesbelarusier.se/belarus-vs-vitryssland?langswitch_ lang $=\mathrm{sv}$

Taras, A. (2016). Kratkij kurs istorii Belarusi IX-XII vv. Charvest.

Temper, E. (2012). Belarus verbildlichen: Staatssymbolik und Nationsbildung seit 1990. Böhlau.

Tiander, K. (1920, 11. januari). Polen: Dess nuvarande tillstånd och resurser. Hufvudstadsbladet.

Törnquist-Plewa, B. (1997). Språk och identitet $i$ Vitryssland: en studie $i$ den vitryska nationalismens historia (=Slavica Lundensia 16). Slaviska institutionen.

Uggla, M. (2013, 6. maj). Namnfrågan handlar inte om endonymer eller exonymer. iöst.nu. https://iost.nu/ blogg/martin-uggla/namnfragan-handlar-inte-om-endonymer-eller-exonymer/

Uggla, M. (2014) Bruksanvisning för diktatorer: En berättelse om Belarus och om Europas först moderna diktator. Ruin.

Uggla, M. (2015, 9. oktober). [författarens diskussion med Uggla på sveriges f.d. vitrysslandsambassadör Stefan Erikssons facebook-vägg]. Facebook. https://www.facebook.com/stefan.eriksson.771 ?fref=ts

Veksler, A. G., Rabinovitj, M. G. \& Sheljapina. N. S. (1973). M.M. Gerasimov i istorija Moskvy (raboty po vosstanovleniju oblika drevnich zjitelei Moskovskaja kraia i russkich tsarei) Antropologitjeskaja rekonstruktsija i problemy paleetnografii (s. 16-37). Idz-vo Nauka.

Viasna, human rights center. (2021). https://prisoners.spring96.org/en. Hämtat 29 oktober 2021.

Vushko, I. (2015). The politics of cultural retreat: Imperial bureaucracy in Austrian Galicia. 1772-1867. Yale University Press.

Weiss-Wendt, A. (2018). A rhetorical crime: Genocide in the geopolitical discourse of the ColdWar. Rutgers University Press.

Wolff, L. (2010). The idea of Galicia: History and fantasy in Habsburg political culture. Stanford University Press.

Yocum, B. B. (2003). Constructing a socialist tower of Babel: Nationality policy in Soviet Belorussia 1921-1933. Brandeis University.

Zaprudnik, J. (1974). The name of Biełaruś (Byelorussia). Facts on Byelorussia: News Bulletin, 1(10), 8691.

Zaprudnik, J. (1975a). Problems in terminology and in the periodization of Belorussian history. Nationalities Papers, 3(2), 25-45.

Zaprudnik, J. (1975b). The name of Byelorussia. East Europe, 3, 12-15.

Za voliu. (1951), 1. [Flygblad]. Förvarat Francis Skaryna Belarusian Library and Museum, North Finchley, London. 